\title{
DURATION OF SYMPTOMATOLOGY AND MEDIAN SEGMENTAL SENSORY LATENCY IN 993 CARPAL TUNNEL SYNDROME HANDS (668 CASES)
}

\author{
JOAO ARIS KOUYOUMDJIAN*
}

\begin{abstract}
According to median sensory nerve action potential onset-latency to index finger in a $140 \mathrm{~mm}$ fixed distance, 993 carpal tunnel syndrome (CTS) hands from 668 patients were grouped into MIld (3.0 to $3.5 \mathrm{~ms}, 384$ hands), MOderate (3.6 to $4.4 \mathrm{~ms}, 332$ hands), SEvere (> $4.4 \mathrm{~ms}, 135$ hands) and UNrecordable (142 hands) and correlated with CTS symptomatology duration. All patients have sensory antidromic median-radial latency difference (MRD) e $\geq 1.0 \mathrm{~ms}$ without any doubt about CTS diagnosis. Patients with systemic disease, trauma or previous surgery were excluded. There is a remarkable cumulative percentage increase from 1 to 12 months in group UN (3.5\% to $38.7 \%, 11$ folds), much less than the group MI (13.8\% to 54.6\%, 3.9 folds). There is also a remarkable non-cumulative percentage increase in group UN, from 1 to 4-12 months; the group MI had a relatively uniform distribution in all symptomatic duration groups from 1 to $>60$ months. The conclusion is that median nerve compression at carpal tunnel can lead to unrecordable potentials in a relatively short period from 1 to 12 months of evolution, suggesting acute/subacute deterioration. Electrophysiological evaluation must be done periodically in patients that underwent clinical treatment, since cumulative $38.7 \%$ of group UN was found in 12 months period.
\end{abstract}

KEY WORDS: carpal tunnel syndrome, median nerve, compression neuropathy, nerve conduction study.

\section{Síndrome do túnel do carpo: duração da sintomatologia e latência sensitiva segmentar do nervo mediano em 993 mãos (668 pacientes)}

RESUMO - Foram selecionados 668 pacientes (993 mãos) com síndrome do túnel do carpo (STC); o critério de inclusão baseou-se na diferença de latência sensitiva mediano-radial (DMR) $\geq 1,0 \mathrm{~ms}$, não deixando dúvida quanto ao diagnóstico de STC. Pacientes com doenças sistêmicas conhecidas, trauma e cirurgia prévia foram excluídos. A partir dessa amostra foram constituídos 4 grupos de acordo com a latência distal sensitiva do nervo mediano, segmento punho - II dedo, 140 mm: LEve (3,0 a 3,5 ms, 384 mãos), MOderado (3,6 a 4,4 ms, 332 mãos), GRave (> 4,4 ms, 135 mãos) e INexcitável (142 mãos); os grupos foram correlacionados com tempo de sintomatologia do STC. Houve aumento percentual cumulativo importante de 1 a 12 meses de sintomatologia no grupo IN (3,5\% a 38,7\%, aumento de 11 vezes); no grupo LE, o aumento foi de 3,9 vezes (13,8\% a 54,6\%). Houve também aumento percentual não cumulativo importante no grupo IN entre 1 e 4-12 meses de sintomatologia e quase o mesmo número em todas as faixas ( $1 \mathrm{a}>60$ meses) no grupo LE. A compressão do nervo mediano no túnel do carpo pode conduzir a quadro eletrofisiológico grave (ausência de potenciais de ação sensitivos) em período de tempo relativamente curto de 12 meses, sugerindo deterioração aguda ou subaguda. Reavaliação eletrofisiológica deve ser feita periodicamente mesmo nos casos leves com tratamento conservador, pois $38,7 \%$ cumulativo do grupo IN foi encontrado em período de 12 meses de sintomatologia.

PALAVRAS-CHAVE: síndrome do túnel do carpo, nervo mediano, neuropatia compressiva, condução nervosa.

Department of Neurological Sciences, Clinical Neurophysiology, EMG Lab, Faculty of Medicine, São José do Rio Preto, São Paulo, Brazil: *MD, MSc, Assistant-Professor. Presented in part at the 43rd Annual Scientific Meeting, American Association of Electrodiagnostic Medicine, Minneapolis, USA, October 1996. Aceite: 13-janeiro-1999.

Dr. Joao Aris Kouyoumdjian - Av. Bady Bassitt 3896 - 15025-000 São José do Rio Preto, SP - Brasil. FAX 5517 2327757. E-mail: jaris@zaz.com.br 
The carpal tunnel syndrome (CTS) symptomatology - nocturnal pain, paraesthesia and numbness - frequently appears as a subacute or chronic disease. The electrodiagnosis of CTS is based on the demonstration of prolonged median sensory nerve action potential latency from at least one median innervated digit, prolonged median motor distal latency from wrist to thenar muscles, mainly abductor pollicis brevis, and prolonged median mixed nerve action latency palm to wrist. Latency difference methods are also used to get more sensitivity: median/ulnar (ring-finger); median/ radial (thumb); median/ulnar (palm-wrist) ${ }^{1-13}$.

The clinical/electrophysiological correlation in CTS is very important, helping to indicate the best form of treatment - clinical conservative or immediate surgical decompression - for that moment ${ }^{1}$. However, we do not know exactly the evolution of median nerve compression: some cases deteriorate slowly through time, some could go further on a complete dennervation and another group maintain the same electrophysiological abnormality for many years ${ }^{14}$. The main goal of this study is to correlate the CTS symptomatology duration and the severity of median sensory conduction abnormality.

\section{METHOD}

From January 1989 to June 1996, 885 patients have CTS electrophysiological confirmation based on sensory antidromic median-radial latency difference (MRD) e $\geq 1.0 \mathrm{~ms}$ that represents mean (m) plus more than 6 standard deviation (SD) without any doubt about CTS diagnosis. Normal MRD was calculated in 125 hands from 70 patients, mean age 36.9 years (17-70), 61 female and 9 male; the results show upper limit of normality $(\mathrm{m}+2 \mathrm{SD})$ equal $0.43 \mathrm{~ms}$

The exclusion criteria were as follows: 1 . unilateral conduction studies; 2 . control examination on the same patient (only the first one was considered); 3. post-operative nerve conduction studies; 4. electrophysiological suspicion of peripheral neuropathy: ulnar sensory action potential $<15 \mathrm{uV}$ and/or ulnar motor conduction velocity $<50.0 \mathrm{~m} / \mathrm{s} ; 5$. recent or remote wrist trauma; 6 . associated known diseases such as diabetes mellitus, rheumatoid arthritis, systemic lupus erythematosus, gout, polymyositis and sclerodermy.

After exclusions, 668 patients and 993 hands were selected for this study. All nerve conduction studies were done by the author in the same EMG machine. The room temperature varied from $20^{\circ} \mathrm{C}$ to $31^{\circ} \mathrm{C}$; hands were warm up in immersion hot water when necessary.

The radial sensory action potential was obtained after antidromic stimulation ( $0.05 \mathrm{~ms}$ duration) on wrist, radial border, $100 \mathrm{~mm}$ distance; the recording on ring electrodes was done in thumb with measured latency on onset. Median sensory action potential to thumb, used for establishing the latency difference, was obtained after antidromic stimulation on wrist, a little more medial but keeping the same cross-line, related to the radial; the recording and measuring were the radial one.

The median sensory distal latency to index finger was obtained after antidromic stimulation on wrist ( $0.05 \mathrm{~ms}$ duration) in a $140 \mathrm{~mm}$ fixed distance (wrist to index finger, WIF); the recording were done on ring electrodes and the measured latencies on onset.

The correlation was done between CTS symptomatology duration, (either nocturnal pain, paraesthesia and numbness) in months at the time of electrodiagnosis examination and antidromic median sensory action potential onset-latency to index finger. Four groups were done: MIld (WIF latency between 3.0 and $3.5 \mathrm{~ms}$ ), MOderate (3.6 - $4.4 \mathrm{~ms}$ ), SEvere (> $4.4 \mathrm{~ms}$ ) and UNrecordable.

Table 1. Cumulative percentage of CTS hands related to symptomatology duration in groups with increased median segmental sensory latency

\begin{tabular}{lcccccc}
\hline Group & $1 \mathrm{~m}$ & $3 \mathrm{~m}$ & $12 \mathrm{~m}$ & $24 \mathrm{~m}$ & $60 \mathrm{~m}$ & $\geq 120 \mathrm{~m}$ \\
\hline Mild & $13.8 \%$ & $26.3 \%$ & $54.6 \%$ & $68.2 \%$ & $85.1 \%$ & $100 \%$ \\
Moderate & $7.5 \%$ & $17.1 \%$ & $50.3 \%$ & $64.4 \%$ & $78.9 \%$ & $100 \%$ \\
Severe & $5.1 \%$ & $13.3 \%$ & $44.4 \%$ & $56.2 \%$ & $66.6 \%$ & $100 \%$ \\
Unrecordable & $3.5 \%$ & $11.9 \%$ & $38.7 \%$ & $52.1 \%$ & $71.1 \%$ & $100 \%$ \\
\hline
\end{tabular}




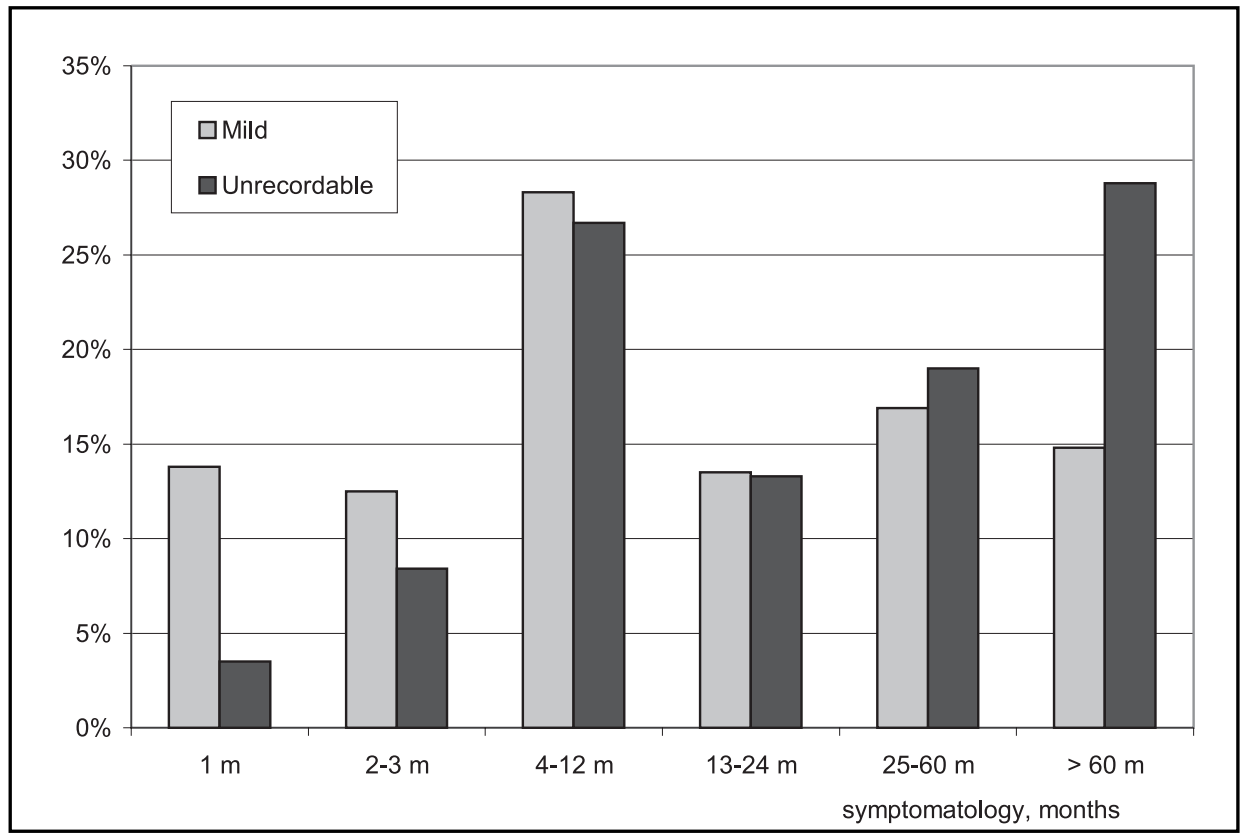

Fig 1. Non-cumulative percentage of CTS hands related to symptomatology duration in two extreme groups of median segmental sensory latency.

\section{RESULTS}

The cumulative percentage of patients on each group were calculated for 1, 3, 12, 24, 60 and equal or more than 120 months (symptomatic CTS duration) and shown on Table 1.

The non-cumulative percentage of patients on 2 extremes groups MI and UN were calculated for 1, 2-3, 4-12, 13-24, 25-60 and above 60 months (symptomatic CTS duration) and is shown on Figure 1.

\section{DISCUSSION}

The results have showed a remarkable cumulative percentage increase from 1 to 12 months in group UN (11 folds, $3.5 \%$ to $38.7 \%$ ) and a lesser increase in the group MI (3.9 folds, $13.8 \%$ to $54.6 \%$ ). The percentage difference between the cumulative patients in groups MI and UN was large at 1 month symptomatology ( $13.8 \%$ and $3.5 \%$ respectively, 2.92 folds) and small at 12 months (54.6\% and $38.7 \%, 0.41$ folds).

The results on non-cumulative percentage in the extreme groups, MI and UN, showed an almost uniform number of patients for the MI ones (13.8\% for one month symptomatology and $14.8 \%$ for above 60 months) and a great increase for the UN ones till 12 months $(3.5 \%$ for one month symptomatology and $26.7 \%$ for $4-12$ months).

The hypothesis of a progressive nerve compression on CTS is not completely true, because one can find mild median sensory conduction abnormalities equally in all groups, varying from 1 to more than 60 months. However, the results also clearly have showed a dramatic increase in the percentage of unrecordable median sensory conduction patients from 1 to 12 months CTS symptomatology. The median nerve compression at carpal tunnel can lead to unrecordable sensory nerve action potentials in a relatively short period from 1 to 12 months of evolution, suggesting 
acute/subacute deterioration. An increase on CTS symptomatology duration does not indicate in all cases a progression in compression severity ${ }^{14,15}$.

Electrophysiological evaluation must be done periodically in patients that underwent clinical conservative treatment, since $38.7 \%$ cumulative and $26.7 \%$ non-cumulative of group UN was found in 12 months period.

\section{REFERENCES}

1. American Academy of Neuroloy. Practice parameter for carpal tunnel syndrome: summary statament. Neurology 1993;43:2406-2409.

2. American Academy of Neurology, American Association of Electrodiagnostic Medicine, American Academy of Physical Medicine and Rehabilitation. Practice parameter for electrodiagnostic studies in carpal tunnel syndrome: summary statament. Neurology 1993;43:2404-2405.

3. Andary MT, Fankhauser MJ, Ritson JL, et al.. Comparison of sensory mid-palm studies to other techniques in carpal tunnel syndrome. Electromyogr Clin Neurophysiol 1996;36:279-285.

4. Carrol GJ. Comparison of median and radial nerve sensory latencies in the electrophysiological diagnosis of carpal tunnel syndrome. Electromyogr Clin Neurophysiol 1987;68:101-106.

5. Dawson DM, Hallett M, Millender LH. Entrapment Neuropathies, 2Ed. Boston: Little, Brown and Co. 1990.

6. Hennessey WJ, Falco FJE, Braddom RL, Goldberg G. The influence of age on distal latency comparisons in carpal tunnel syndrome. Muscle Nerve 1994;17:1215-1217.

7. Jablecki CK, Andary MT, So YT, Wilkins DE, Willians FH. Literature review of the usefulness of nerve conduction studies and electromyography for the evaluation of patients with carpal tunnel syndrome. Muscle Nerve 1993;16:1392-1414.

8. Jackson DA, Clifford JC. Electrodiagnosis of mild carpal tunnel syndrome. Arch Phys Med Rehabil 1989;70:199-204

9. Johnson EW, Kukla RD, Wongsam PE, Piedmont A. Sensory latencies to the ring finger: normal values and ralation to carpal tunnel syndrome. Arch Phys Med Rehabil 1981;62:206-208.

10. Johnson EW, Sipski M, Lammertse T. Median and radial sensory latencies to digit I: normal values and usefulness in carpal tunnel syndrome. Arch Phys Med Rehabil 1987;68:140-141.

11. Kouyoumdjian JA. Sensory median/radial latency difference versus routine conduction studies in 794 carpal tunnel syndrome hands. (Abstr) Muscle Nerve 1995;18:1059-1060.

12. Kouyoumdjian JA, Morita MPA. Sensory nerve conduction sensitivity in 95 mild carpal tunnel syndrome hands (Abstr). Muscle Nerve 1996; 20:1070.

13. Uncini A, Muzio A, Awad J, Manente G, Tafuro M, Gambi D. Sensitivity of three median-to-ulnar comparative tests in diagnosis of mild carpal tunnel syndrome. Muscle Nerve 1993;16:1366-1373.

14. Andary MT, Werner RA. Electrodiagnosis in clinical decision making: carpal tunnel syndrome. San Diego: American Association of Electrodianostic Medicine, 1997 20th Annual Continuing Education Courses. Course B: Using electrodiagnosis in clinical decision making, 11-19.

15. Kouyoumdjian JA. Temporal carpal tunnel syndrome symptomatology and nerve conduction study in 615 patients (Abstr). Muscle Nerve 1996; 19:1200. 